Supporting Information

\title{
Liquid Nitrogen Activation of Zero-Valent Iron and Its Enhanced Cr(VI) Removal Performance
}

Yue Hu, Xing Peng, Zhihui Ai, Falong Jia, * and Lizhi Zhang*

Key Laboratory of Pesticide \& Chemical Biology of Ministry of Education, Institute of

Environmental \& Applied Chemistry, College of Chemistry, Central China Normal University,

Wuhan 430079, People's Republic of China

* To whom correspondence should be addressed. E-mail: fljia@mail.ccnu.edu.cn;

zhanglz@mail.ccnu.edu.cn.

Phone/Fax: +86-27-6786 7535

15 pages, 2 text, 19 figures, 6 tables 


\section{CONTENTS}

Text S1. Surface areas normalized Cr(VI) removal rate constant $k^{\prime} \quad S 4$

Text S2. Inhibitory efficiency calculation method $\quad$ S4

Figure S1. Cr(VI) removal by LZVI with different soaking time in liquid nitrogen $\quad$ S5

Figure S2. Plots of $-\ln \left(\mathrm{C} / \mathrm{C}_{0}\right)$ versus time for $\mathrm{Cr}(\mathrm{VI})$ removal by ZVI samples $\quad$ S5

Figure S3. Nitrogen adsorption-desorption isotherms of ZVI samples $\quad$ S6

Figure S4. Open-circuit potentials of ZVI samples $\quad$ S6

Figure S5. Cr(VI) removal by ZVI samples in the presence of 1,10-phenanthroline $\quad$ S6

$\begin{array}{ll}\text { Figure S6. Concentrations of Fe(II) released over ZVI samples } & \text { S7 }\end{array}$

Figure S7. pH change during the Cr(VI) removal over ZVI samples $\quad$ S7

Figure S8. Cr(VI) removal by ZVI samples under different initial $\mathrm{pH}$ values $\quad$ S8

$\begin{array}{ll}\text { Figure S9. AFM image of LZVI and depth of the fracture } & \text { S8 }\end{array}$

Figure S10. Structure characterizations of ZVI samples $\quad$ S9

Figure S11. Hysteresis loops of ZVI samples recorded at $300 \mathrm{~K} \quad$ S9

$\begin{array}{ll}\text { Figure S12. XPS spectra of ZVI samples } & \text { S10 }\end{array}$

Figure S13. SEM images of ZVI samples reacted with Cr(VI) S10

Figure S14. Reusability of LZVI in Cr(VI) removal process $\quad$ S11

Figure S15. SEM coupled mapping images of ZVI reacted with Cr(VI) S11

Figure S16. XRD patterns of ZVI samples reacted withCr(VI) S11

Figure S17. Survey XPS spectra of ZVI samples reacted with Cr(VI) S12

Figure S18. Cr(VI) removal by ZVI samples with different particle sizes $\quad$ S12

Figure S19. Cr(VI) removal by ZVI samples from different suppliers $\quad$ S13

Table S1. The normalized Cr(VI) removal rate constant $k^{\prime}$ with BET surface areas $\quad$ S13 
Table S4. Ratios of $\mathrm{Fe}^{0}, \mathrm{Fe}(\mathrm{II}), \mathrm{Fe}(\mathrm{III})$ to $\mathrm{Fe}_{\text {total }}$ in the Fe 2p HR-XPS spectra of ZVI and LZVI S14 Table S5. Ratios of Fe-O, Fe-OH, $\mathrm{H}_{2} \mathrm{O}$ to $\mathrm{O}_{\text {total }}$ in the $\mathrm{O}$ 1s HR-XPS spectra of ZVI and LZVI S15 
Text S1. Surface areas normalized $\mathrm{Cr}(\mathrm{VI})$ removal rate constant $\boldsymbol{k}^{\prime}$

The BET surface area normalized Cr(VI) removal rate constant $k^{\prime}\left(\mathrm{g} \cdot \mathrm{min}^{-1} \bullet \mathrm{m}^{-2}\right)$ was calculated (eq 1).

$$
k^{\prime}=k / S_{\mathrm{BET}}
$$

where $k$ and $S_{\text {BET }}$ are the $\mathrm{Cr}(\mathrm{VI})$ removal rate constant $\left(\mathrm{min}^{-1}\right)$ and BET surface area $\left(\mathrm{m}^{2} \mathrm{~g}^{-1}\right)$, respectively. The same trend of normalized rate constants $\left(k^{\prime}\right)$ as that of the initial ones $(k)$ ruled out the contribution of the surface area to the $\mathrm{Cr}(\mathrm{VI})$ removal performance.

\section{Text S2. Inhibitory efficiency calculation method.}

$$
\eta=\left[\left(k-k_{\mathrm{t}}\right) / k\right] \times 100 \%
$$

where $k$ and $k_{\mathrm{t}}$ are the apparent $\mathrm{Cr}(\mathrm{VI})$ removal rate constants in the absence and presence of 1,10-phenanthroline, respectively. 


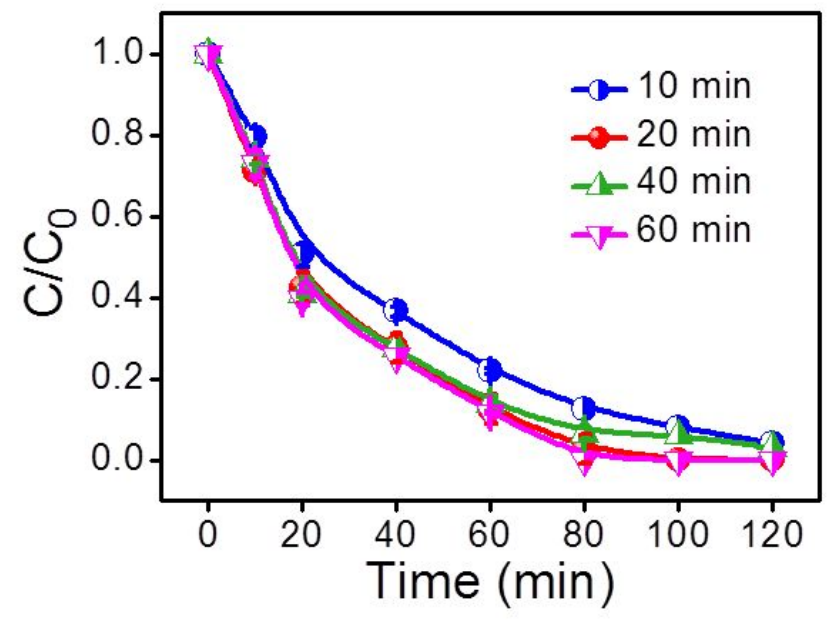

Figure S1. Cr(VI) removal as a function of time by LZVI with different soaking time in liquid nitrogen for 10, 20, 40, and $60 \mathrm{~min}$.

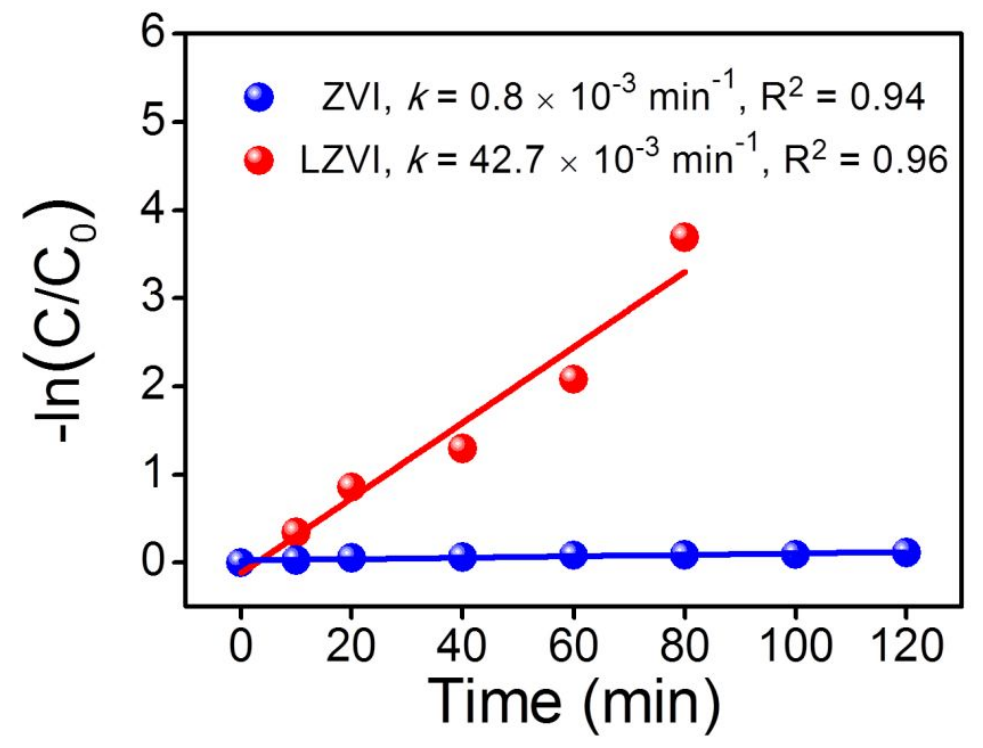

Figure S2. Plots of $-\ln \left(\mathrm{C} / \mathrm{C}_{0}\right)$ versus time for the $\mathrm{Cr}(\mathrm{VI})$ removal by $\mathrm{ZVI}$ and LZVI. The initial concentrations of ZVI samples and $\mathrm{Cr}(\mathrm{VI})$ were $5 \mathrm{~g} \mathrm{~L}^{-1}, 2.0 \mathrm{mg} \mathrm{L}^{-1}$, respectively. 

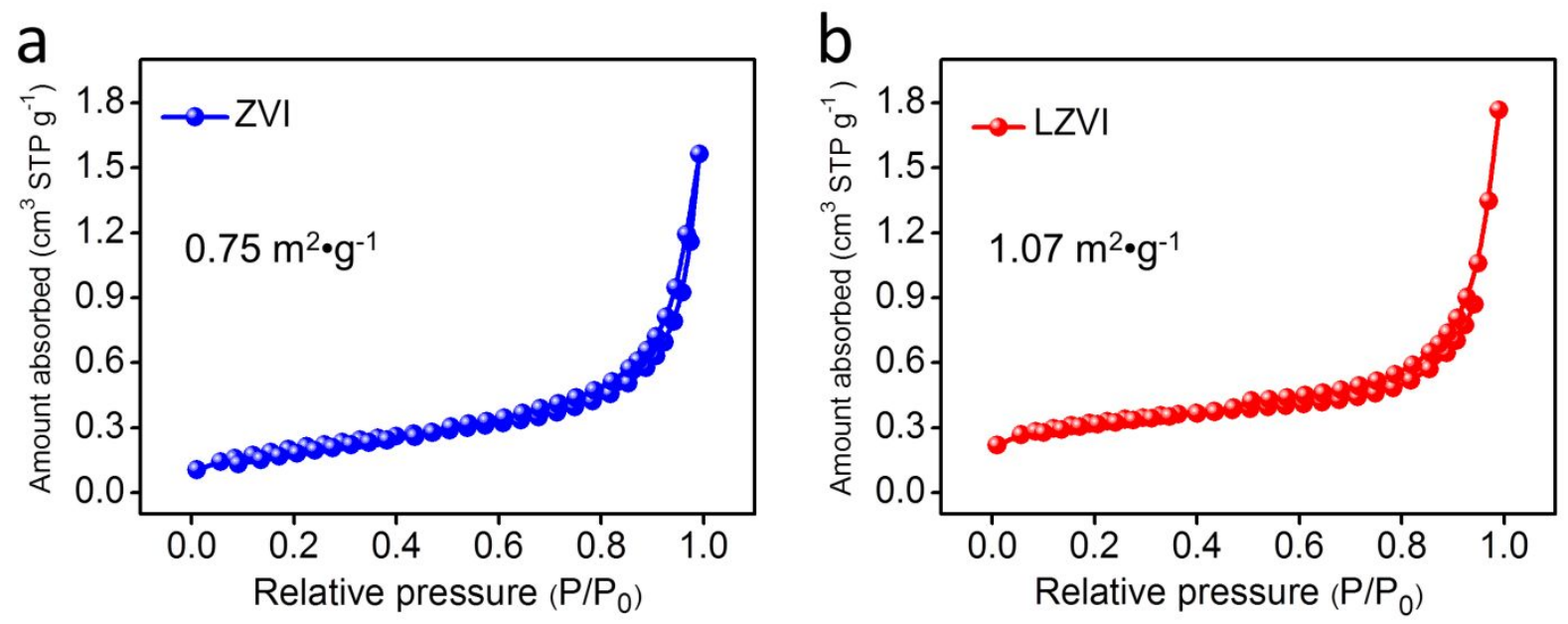

Figure S3. Nitrogen adsorption-desorption isotherms of ZVI (a) and LZVI (b).

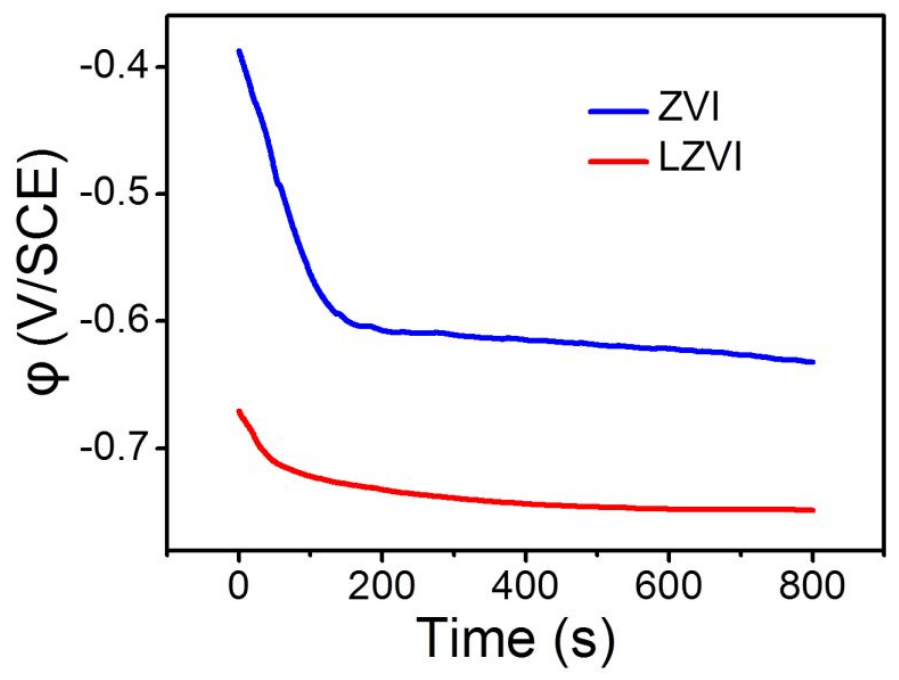

Figure S4. Open-circuit potentials of ZVI and LZVI in the $0.5 \mathrm{~mol} \mathrm{~L}^{-1} \mathrm{Na}_{2} \mathrm{SO}_{4}$ solution.
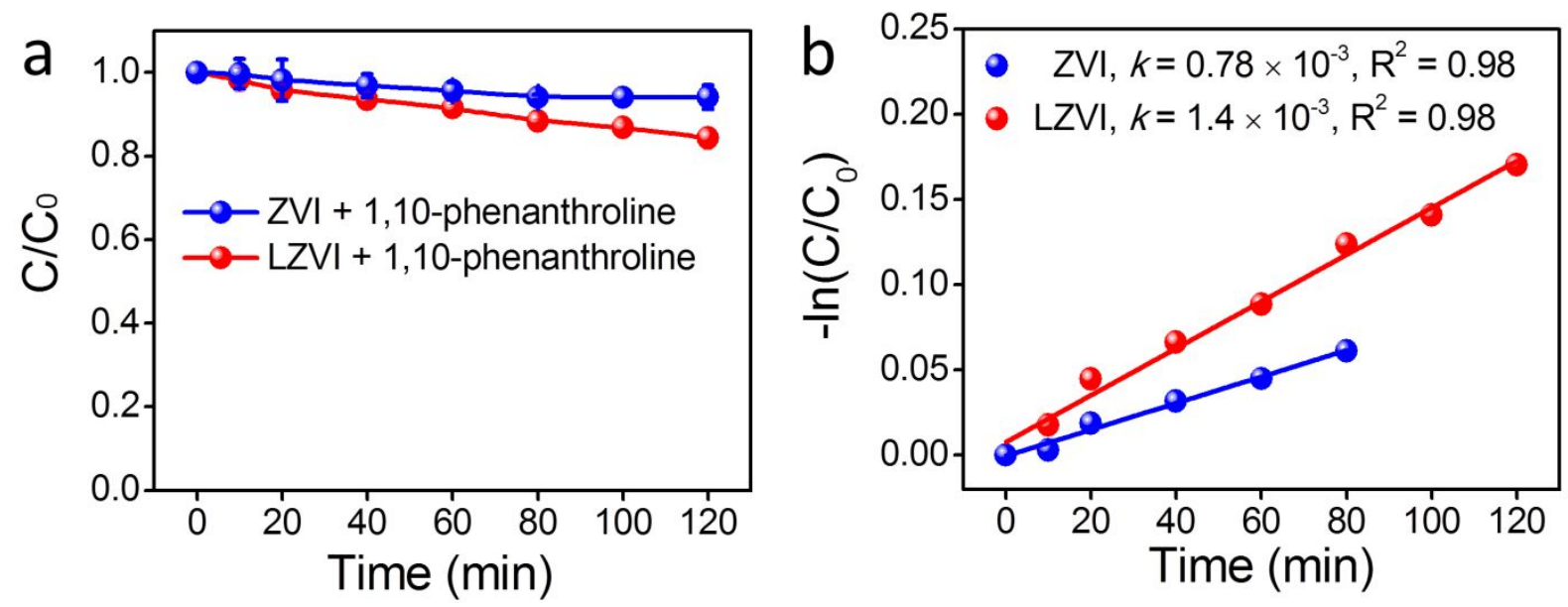

Figure S5. (a) $\mathrm{Cr}(\mathrm{VI})$ removal by ZVI and LZVI in the presence of 1,10-phenanthroline and (b) the corresponding plots of $-\ln \left(\mathrm{C} / \mathrm{C}_{0}\right)$ versus time for the $\mathrm{Cr}(\mathrm{VI})$ removal. The initial concentrations of ZVI samples, 1,10-phenanthroline, and $\mathrm{Cr}(\mathrm{VI})$ were $5 \mathrm{~g} \mathrm{~L}^{-1}, 2 \mathrm{~g} \mathrm{~L}^{-1}$, and $2.0 \mathrm{mg} \mathrm{L}^{-1}$, respectively. 

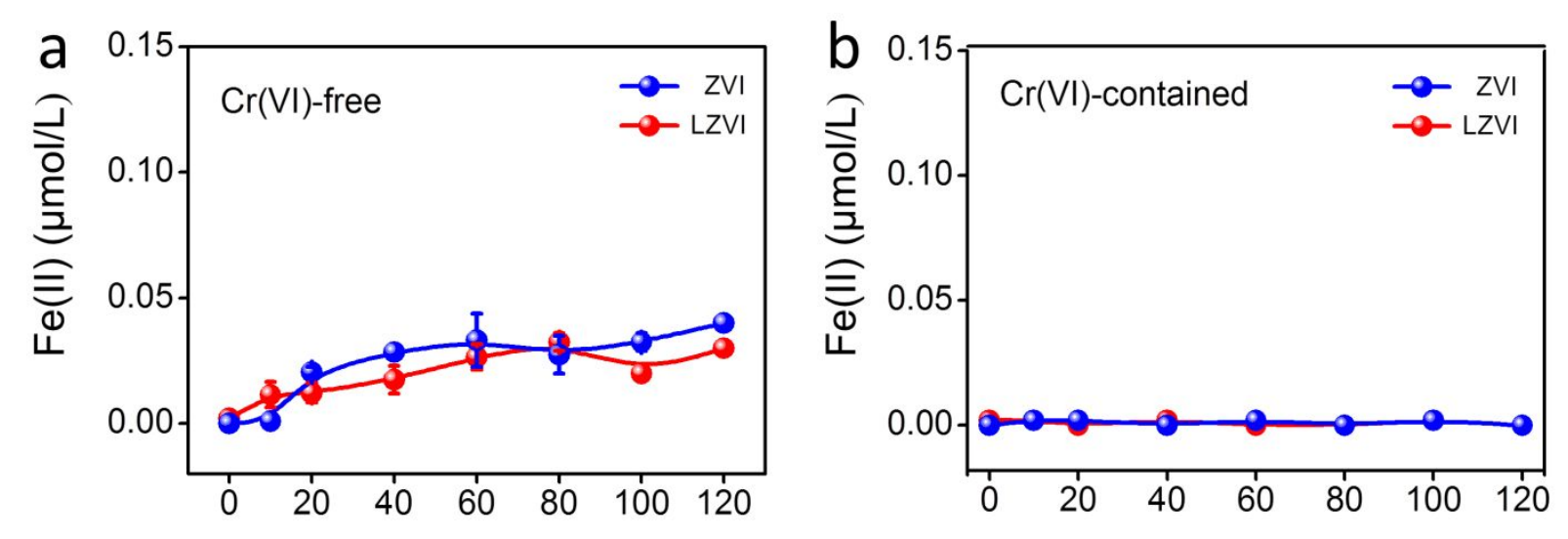

Figure S6. Concentrations of $\mathrm{Fe}(\mathrm{II})$ as a function of time in $\mathrm{Cr}(\mathrm{VI})$-free (a) and $\mathrm{Cr}(\mathrm{VI})$-contained (b) conditions over ZVI and LZVI. The initial concentrations of ZVI samples were $5 \mathrm{~g} \mathrm{~L}^{-1}$.

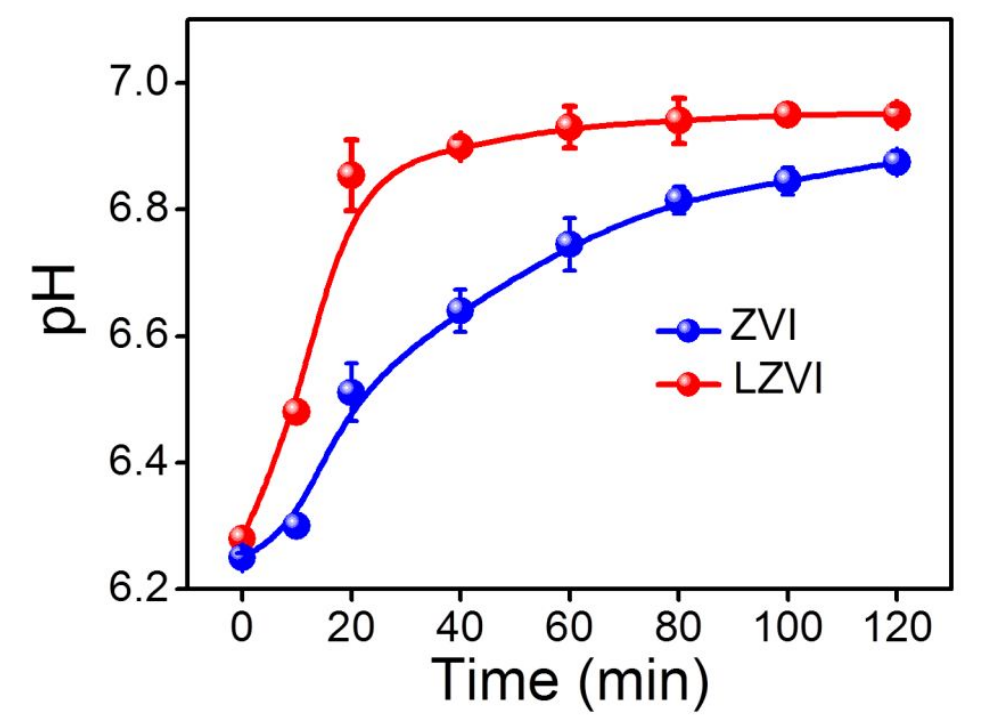

Figure S7. $\mathrm{pH}$ change as a function of reaction time during the $\mathrm{Cr}(\mathrm{VI})$ removal over ZVI and LZVI. The initial $\mathrm{pH}$ was 6.28. The initial concentrations of ZVI samples and $\mathrm{Cr}(\mathrm{VI})$ were $5 \mathrm{~g} \mathrm{~L}^{-1}$ and 2.0 $\mathrm{mg} \mathrm{L}^{-1}$, respectively. 

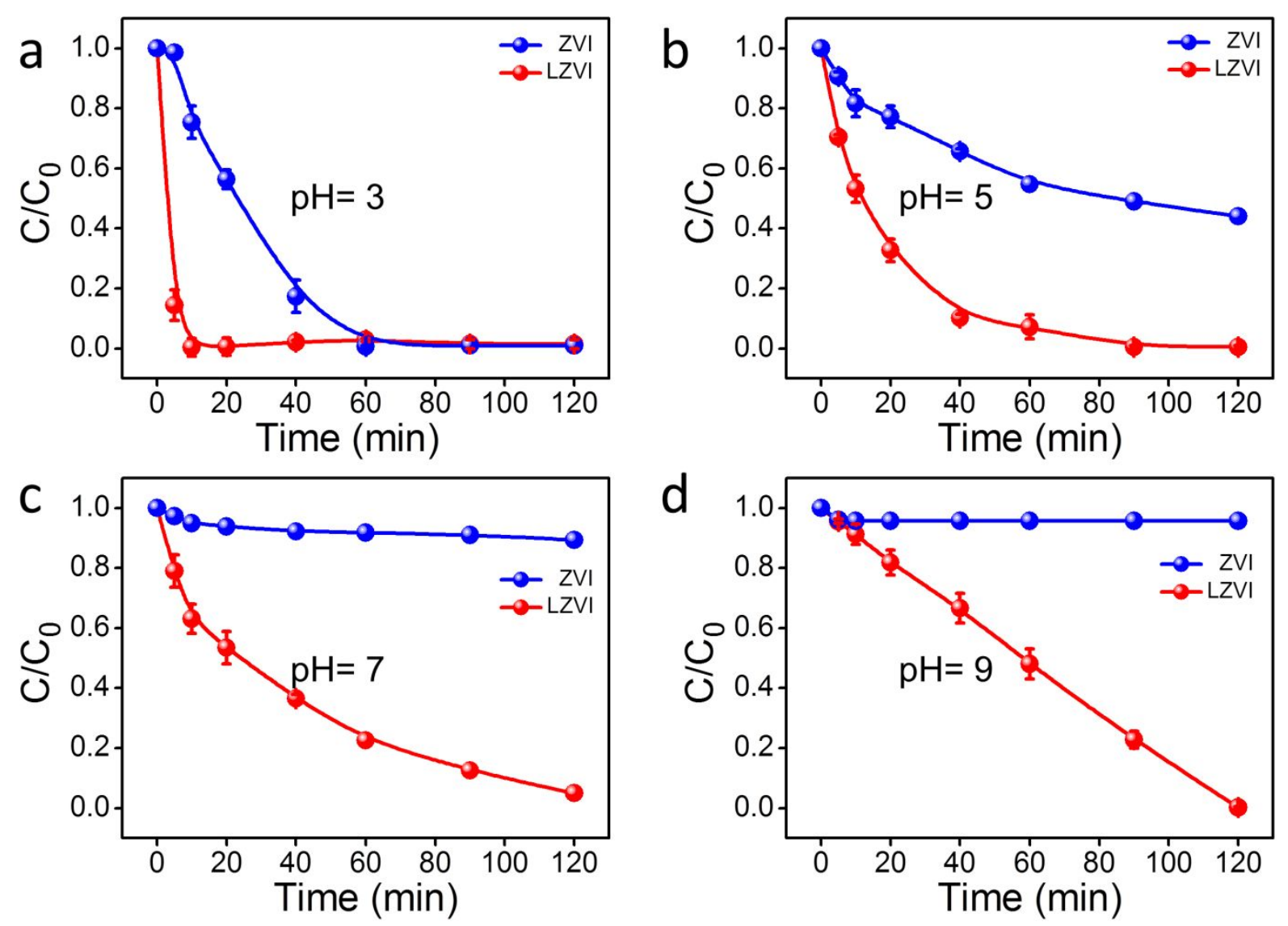

Figure S8. Cr(VI) removal as a function of time by ZVI and LZVI under different initial $\mathrm{pH}$ values:

(a) $\mathrm{pH}=3$, (b) $\mathrm{pH}=5$, (c) $\mathrm{pH}=7$, and (d) $\mathrm{pH}=9$.
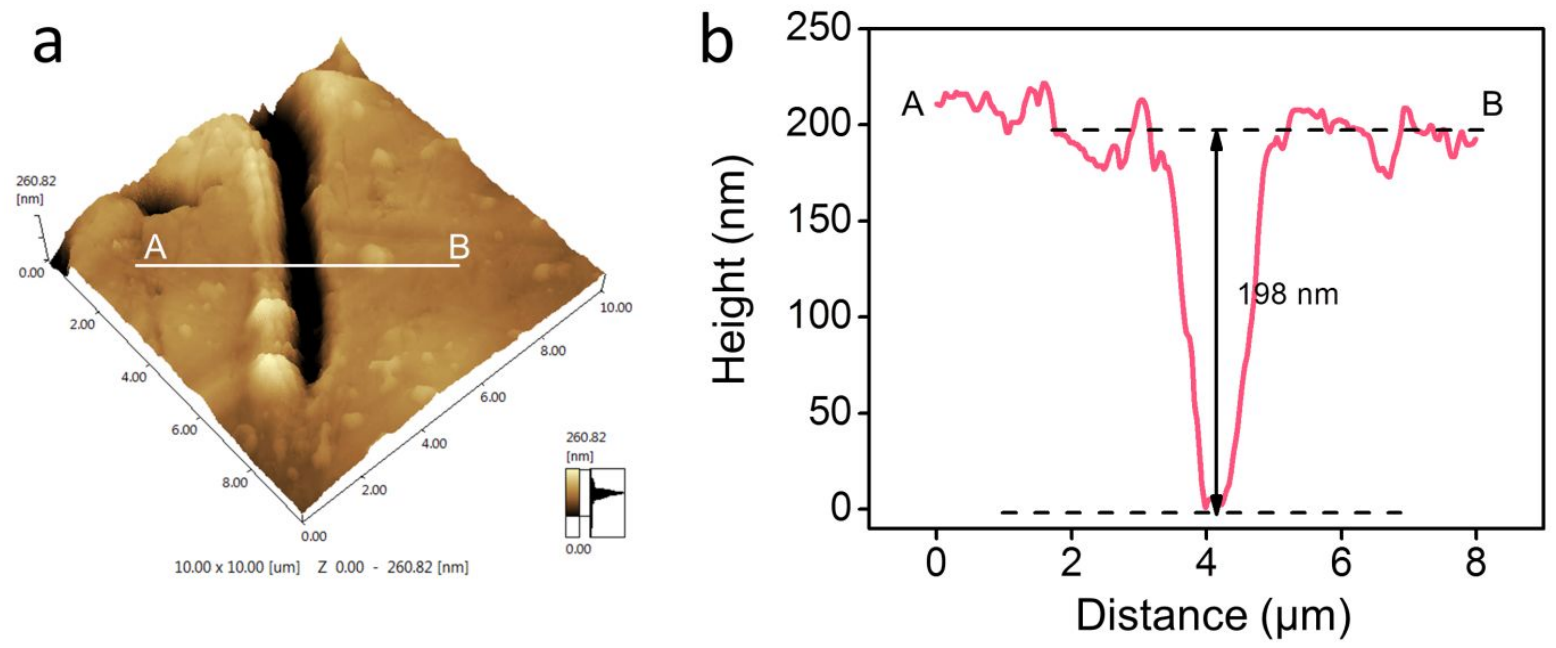

Figure S9. (a) AFM image of LZVI sample. (b) Depth of the fracture measured by AFM. 

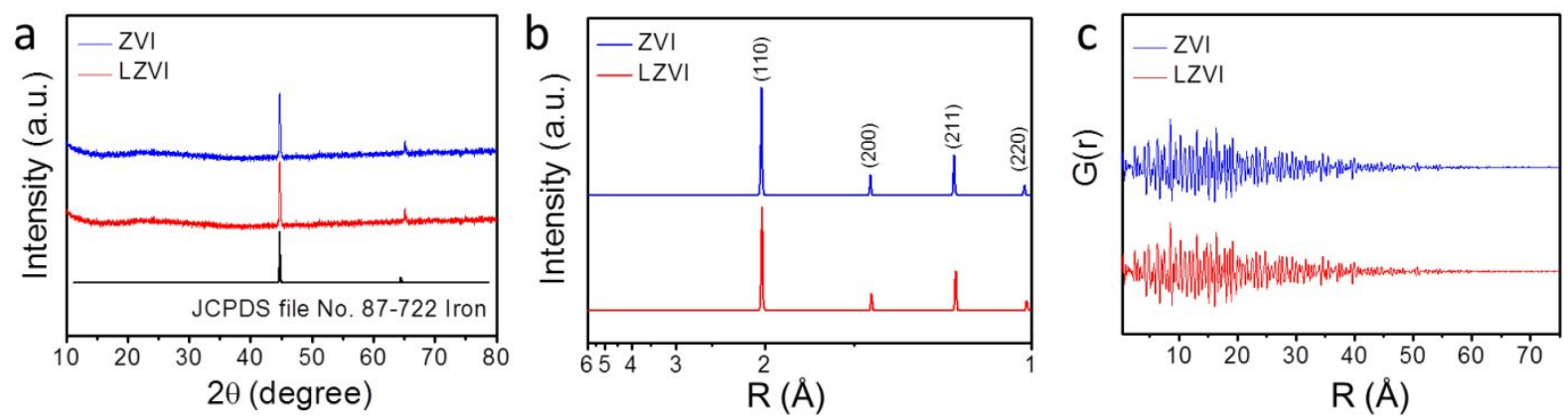

Figure S10. Structure characterizations of ZVI and LZVI: (a) XRD patterns, (b) synchrotron based pair distribution function (PDF) analysis, and (c) G(r).

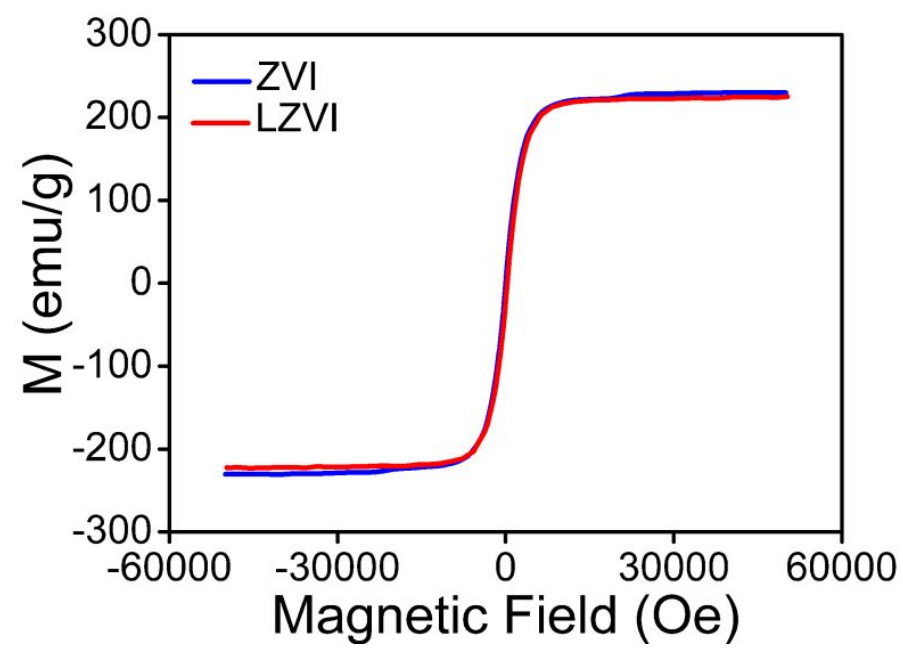

Figure S11. Hysteresis loops of ZVI and LZVI recorded at $300 \mathrm{~K}$. 

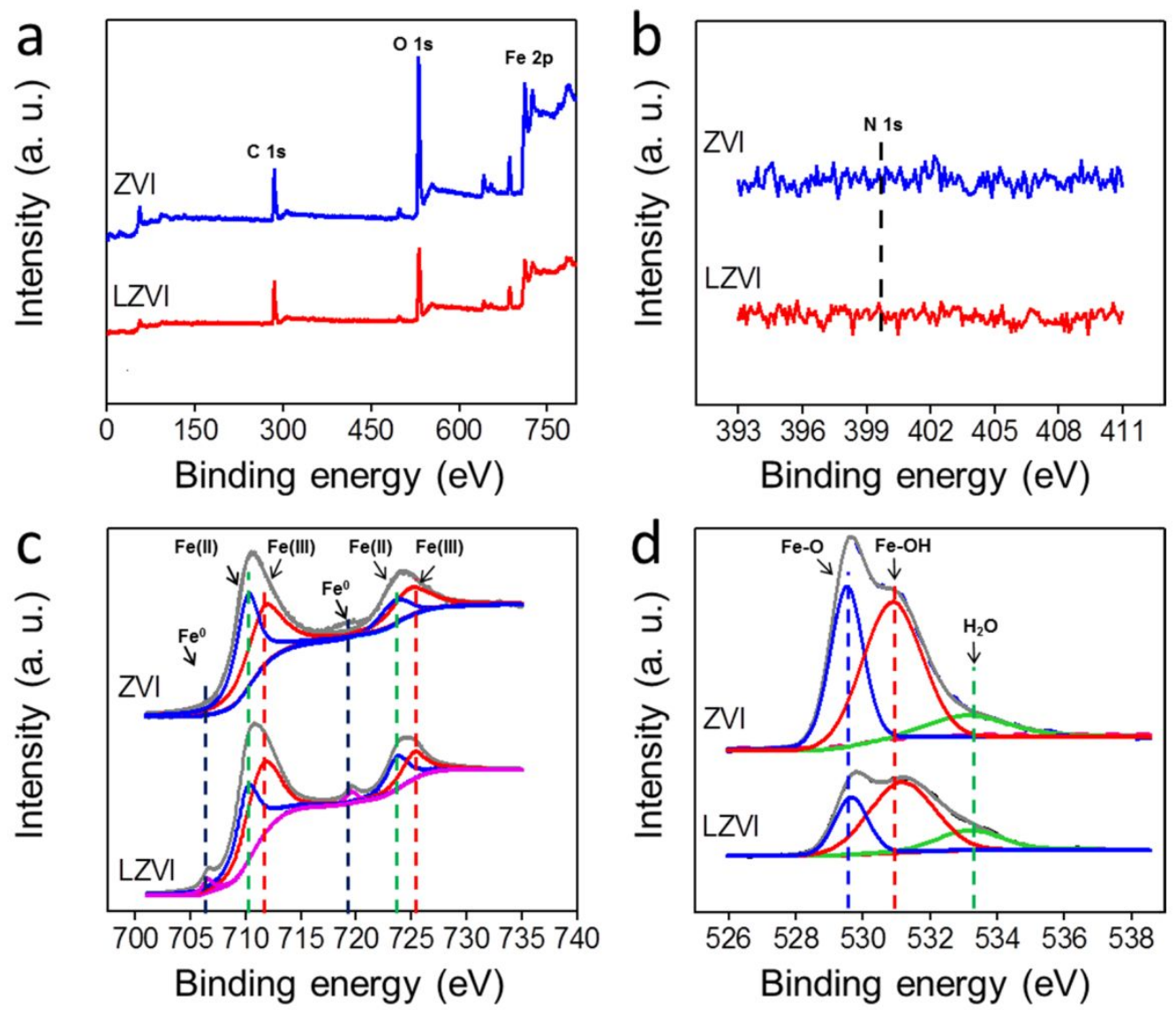

Figure S12. XPS spectra of ZVI and LZVI: (a) Survey, (b) N 1s, (c) Fe 2p, and (d) O 1s HR-XPS.

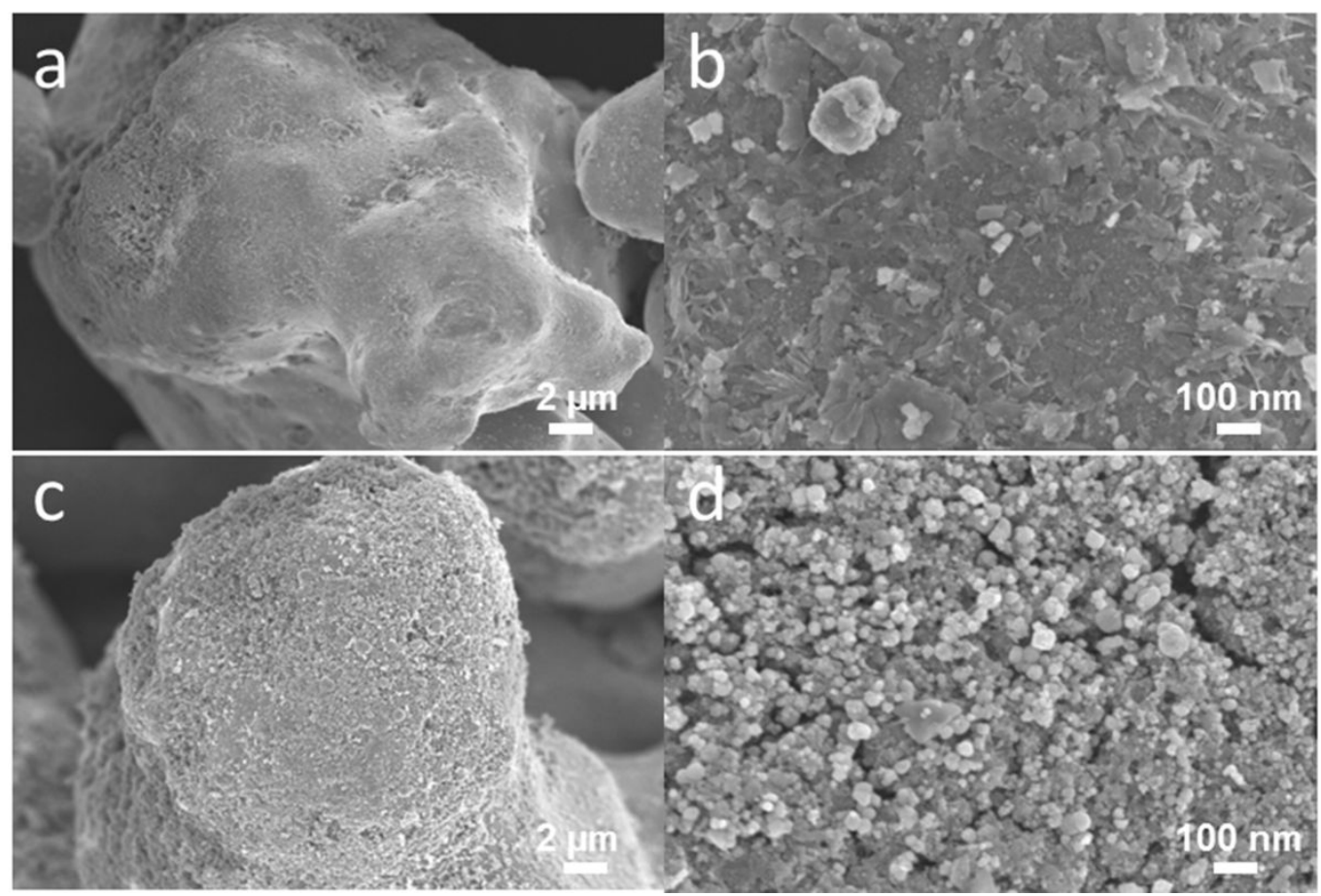

Figure S13. SEM images of ZVI (a, b) and LZVI (c, d) reacted with $\mathrm{Cr}(\mathrm{VI})$ for $120 \mathrm{~min}$. The initial concentrations of ZVI samples and $\mathrm{Cr}(\mathrm{VI})$ were $5 \mathrm{~g} \mathrm{~L}^{-1}$ and $2.0 \mathrm{mg} \mathrm{L}^{-1}$, respectively. 


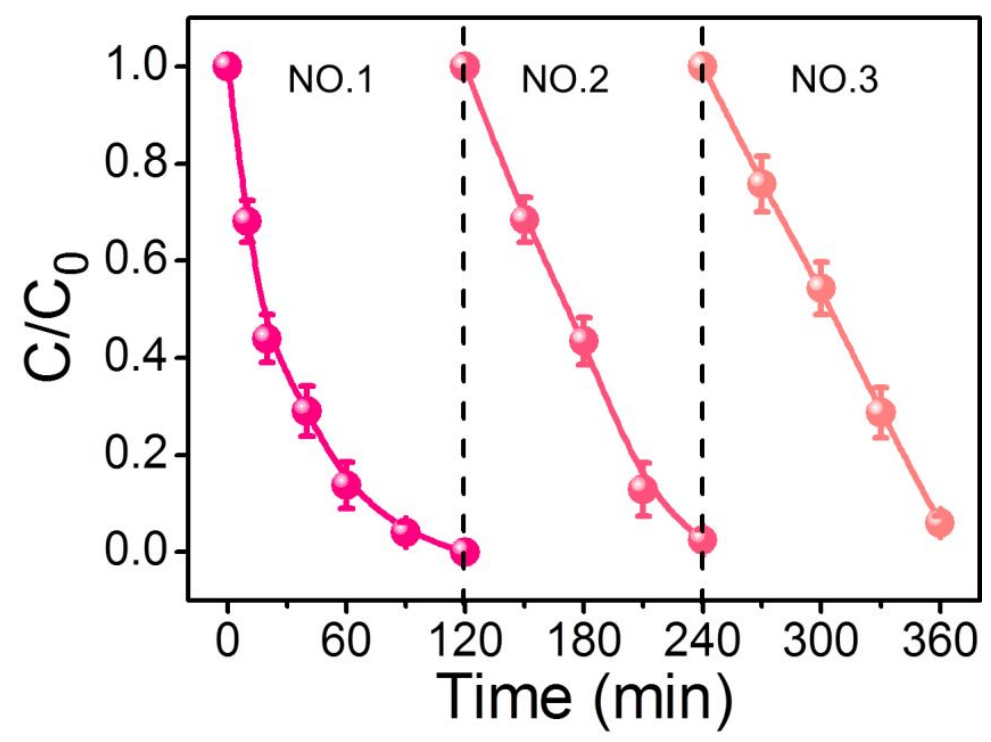

Figure S14. Reusability of LZVI in the Cr(VI) removal process. The initial concentrations of LZVI sample and $\mathrm{Cr}(\mathrm{VI})$ were $5 \mathrm{~g} \mathrm{~L}^{-1}$ and $2.0 \mathrm{mg} \mathrm{L}^{-1}$, respectively.

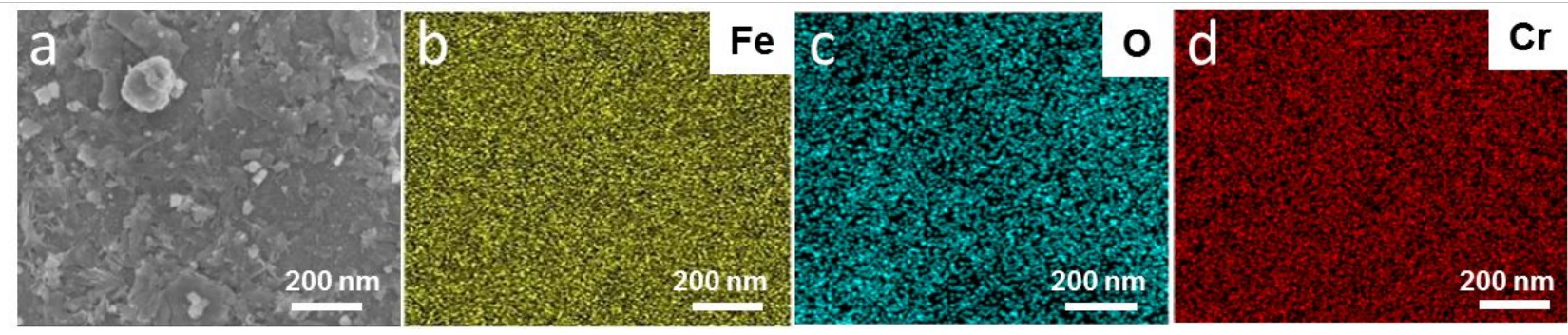

Figure S15. SEM coupled mapping images of ZVI (a-d) reacted with Cr(VI) for $120 \mathrm{~min}$. The initial concentrations of ZVI and $\mathrm{Cr}(\mathrm{VI})$ were $5 \mathrm{~g} \mathrm{~L}^{-1}$ and $2.0 \mathrm{mg} \mathrm{L}^{-1}$, respectively.

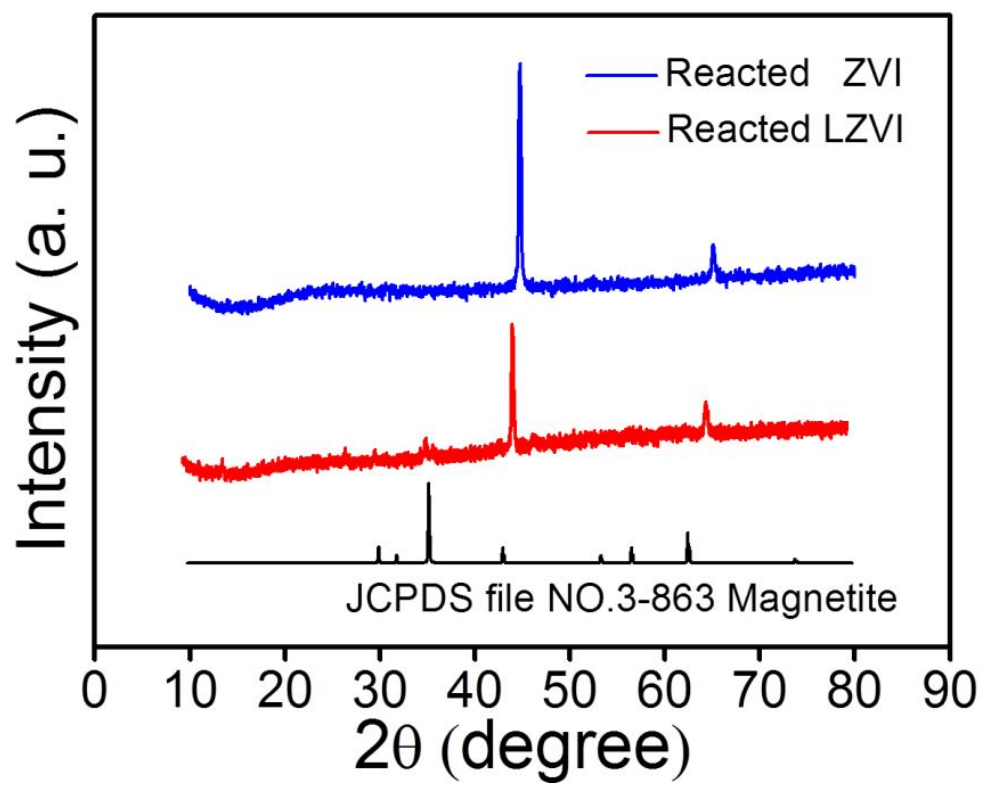

Figure S16. XRD patterns of ZVI and LZVI reacted with $2 \mathrm{mg} \mathrm{L}^{-1} \mathrm{Cr}(\mathrm{VI})$ for $120 \mathrm{~min}$. 

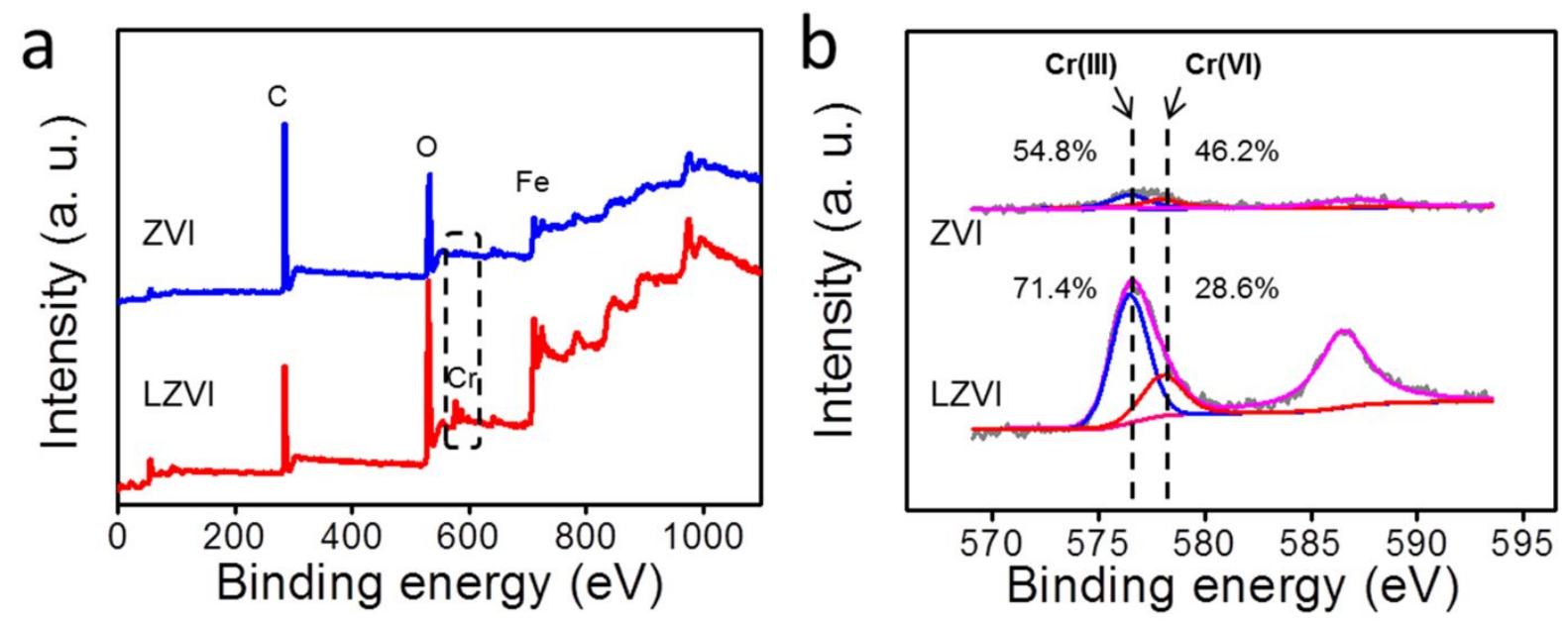

Figure S17. Survey XPS spectra (a) and Cr 2p HR-XPS spectra (b) of ZVI and LZVI reacted with 2 $\mathrm{mg} \mathrm{L}^{-1} \mathrm{Cr}(\mathrm{VI})$ for $120 \mathrm{~min}$.
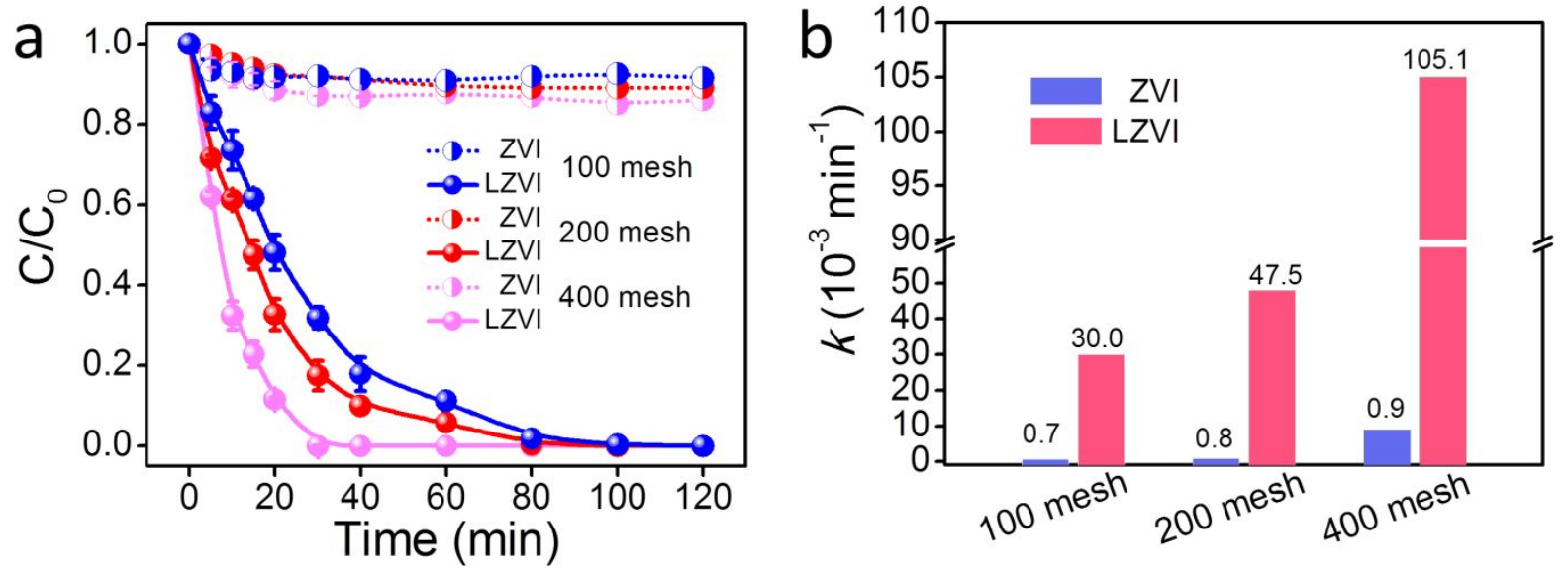

Figure S18. (a) Cr(VI) removal by ZVIs with different particle sizes: 100, 200, 400 mesh and (b) the corresponding apparent $\mathrm{Cr}(\mathrm{VI})$ removal rate constant $k$. Corresponding LZVI samples were synthesized by the same process of liquid nitrogen treatment. The initial concentrations of ZVI samples and $\mathrm{Cr}(\mathrm{VI})$ were $5 \mathrm{~g} \mathrm{~L}^{-1}$ and $2.0 \mathrm{mg} \mathrm{L}^{-1}$, respectively. 


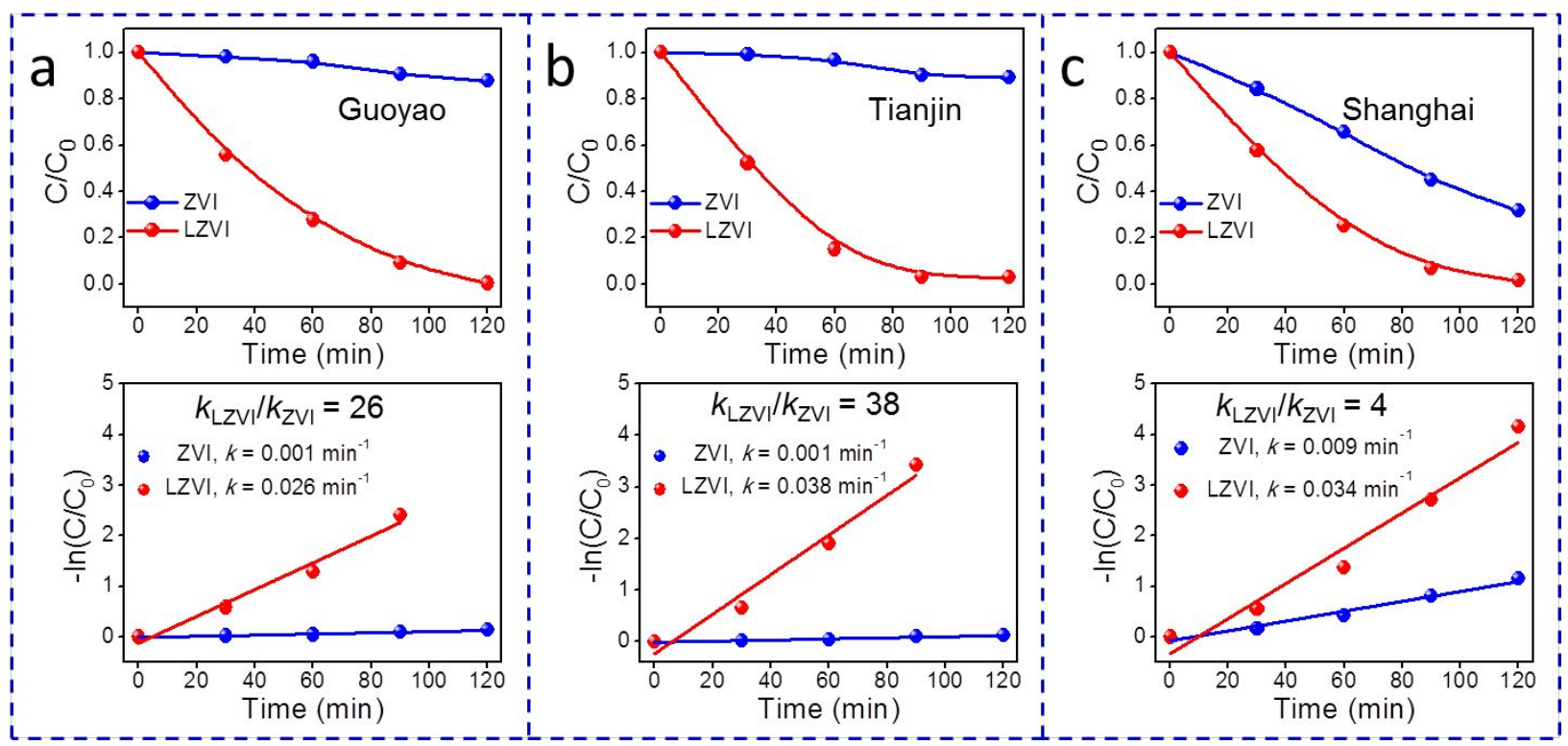

Figure S19. The removal performance of $\mathrm{Cr}(\mathrm{VI})$ and plots of $-\ln (\mathrm{C} / \mathrm{C} 0)$ versus time by commercial ZVIs from different suppliers: (a) Guoyao, (b) Tianjin, and (c) Shanghai ZVI samples. Corresponding LZVI samples were synthesized by the same process of liquid nitrogen treatment. The initial concentrations of ZVI samples and $\mathrm{Cr}(\mathrm{VI})$ were $5 \mathrm{~g} \mathrm{~L}-1$ and $2.0 \mathrm{mg} \mathrm{L}-1$, respectively.

Table S1. The Cr(VI) removal rate constant $k\left(10^{-3} \mathrm{~min}^{-1}\right)$, BET surface area $\left(\mathrm{m}^{2} \mathrm{~g}^{-1}\right)$ and the BET surface areas normalized $\mathrm{Cr}(\mathrm{VI})$ removal rate constant $k^{\prime}\left(\mathrm{g} \cdot \mathrm{min}^{-1} \cdot \mathrm{m}^{-2}\right)$ calculated by the formula from Text S1 (Supporting Information).

\begin{tabular}{cccc}
\hline Samples & $k\left(10^{-3} \mathrm{~min}^{-1}\right)$ & BET surface area $\left(\mathrm{m}^{2} \mathrm{~g}^{-1}\right)$ & $k^{\prime}\left(10^{-3} \mathrm{~g} \cdot \mathrm{min}^{-1} \bullet \mathrm{m}^{-2}\right)$ \\
\hline ZVI & 0.8 & 0.75 & 1.06 \\
\hline LZVI & 42.7 & 1.07 & 39.9 \\
\hline
\end{tabular}


Table S2. The Cr(VI) removal rate constant $k$ (in the absence of 1,10-phenanthroline) and $k_{t}$ (in the presence of 1,10-phenanthroline) over ZVI samples, and inhibitory efficiency calculated by the formula from Text S2 (Supporting Information).

\begin{tabular}{cccc}
\hline Samples & $k\left(10^{-3} \mathrm{~min}^{-1}\right)$ & $k_{t}\left(10^{-3} \mathrm{~min}^{-1}\right)$ & Inhibitory efficiency \\
\hline ZVI & 0.8 & 0.78 & $2.5 \%$ \\
\hline LZVI & 42.7 & 1.4 & $96.7 \%$ \\
\hline
\end{tabular}

Table S3. Contributions of $\mathrm{Fe}^{0}$, Fe(II) (released $\mathrm{Fe}(\mathrm{II})$ and surface bound $\mathrm{Fe}(\mathrm{II})$ ) to the $\mathrm{Cr}(\mathrm{VI})$ removal over ZVI samples.

\begin{tabular}{ccccc}
\hline Samples & $\mathrm{Fe}^{0}(\%)$ & $\mathrm{Fe}(\mathrm{II})(\%)$ & Released Fe(II) (\%) & Surface bound Fe(II) (\%) \\
\hline ZVI & $97.5 \%$ & $2.5 \%$ & $0.04 \%$ & $2.46 \%$ \\
\hline LZVI & $3.3 \%$ & $96.7 \%$ & $0.04 \%$ & $96.66 \%$ \\
\hline
\end{tabular}

Table S4. Ratios of metallic iron to total iron $\left(\mathrm{Fe}^{0} / \mathrm{Fe}_{\text {total }}\right)$, ferrous iron to total iron ( $\left.\mathrm{Fe}(\mathrm{II}) / \mathrm{Fe}_{\text {total }}\right)$, and ferric iron to total iron (Fe(III)/Fe $\mathrm{Ftat}_{\text {tal }}$ in the $\mathrm{Fe} 2 \mathrm{p}$ HR-XPS spectra calculated from the results in Figure S12c (Supporting Information).

\begin{tabular}{cccc}
\hline Samples & $\mathrm{Fe}^{0} / \mathrm{Fe}_{\text {total }}$ & $\mathrm{Fe}(\mathrm{II}) / \mathrm{Fe}_{\text {total }}$ & $\mathrm{Fe}(\mathrm{III}) / \mathrm{Fe}_{\text {total }}$ \\
\hline ZVI & $0.0 \%$ & $44.9 \%$ & $55.1 \%$ \\
\hline LZVI & $5.4 \%$ & $44.8 \%$ & $49.8 \%$ \\
\hline
\end{tabular}


Table S5. Ratios of lattice oxygen to total oxygen $\left(\mathrm{Fe}-\mathrm{O} / \mathrm{O}_{\text {total }}\right)$, hydroxyl oxygen to total oxygen $\left(\mathrm{Fe}-\mathrm{OH} / \mathrm{O}_{\text {total }}\right)$, and adsorbed water to total oxygen $\left(\mathrm{H}_{2} \mathrm{O} / \mathrm{O}_{\text {total }}\right)$ in the $\mathrm{O} 1 \mathrm{~s}$ HR-XPS spectra calculated from the results in Figure S12d (Supporting Information).

\begin{tabular}{cccc}
\hline Samples & Fe-O/O total & Fe-OH/O & $\mathrm{H}_{2} \mathrm{O} / \mathrm{O}_{\text {total }}$ \\
\hline ZVI & $35.7 \%$ & $51.5 \%$ & $12.8 \%$ \\
\hline LZVI & $25.1 \%$ & $57.3 \%$ & $17.6 \%$ \\
\hline
\end{tabular}

Table S6. Ratios of $\mathrm{Cr}(\mathrm{III}), \mathrm{Cr}(\mathrm{VI})$ to $\mathrm{Cr}_{\text {total }}$ in the $\mathrm{Cr} 2 \mathrm{p}$ HR-XPS spectra calculated from the results in Figure S17b (Supporting Information).

\begin{tabular}{ccc}
\hline Samples & $\mathrm{Cr}(\mathrm{III}) / \mathrm{Cr}_{\text {total }}$ & $\mathrm{Cr}(\mathrm{VI}) / \mathrm{Cr}_{\text {total }}$ \\
\hline ZVI & $54.8 \%$ & $45.2 \%$ \\
\hline LZVI & $71.4 \%$ & $28.6 \%$ \\
\hline
\end{tabular}

